\title{
Impacts of the invasive round goby (Neogobius melanostomus) on benthic invertebrate fauna: a case study from the Baltic Sea
}

van Deurs, Mikael; Moran, Nicholas P.; Schreiber Plet-Hansen, Kristian; Dinesen, Grete E.; Azour, Farivar; Carl, Henrik; Møller, Peter R.; Behrens, Jane W.

\section{Published in:}

NeoBiota

Link to article, DOI:

$10.3897 /$ neobiota.68.67340

Publication date:

2021

Document Version

Publisher's PDF, also known as Version of record

Link back to DTU Orbit

Citation (APA):

van Deurs, M., Moran, N. P., Schreiber Plet-Hansen, K., Dinesen, G. E., Azour, F., Carl, H., Møller, P. R., \& Behrens, J. W. (2021). Impacts of the invasive round goby (Neogobius melanostomus) on benthic invertebrate fauna: a case study from the Baltic Sea. NeoBiota, 68, 19-30. https://doi.org/10.3897/neobiota.68.67340

\section{General rights}

Copyright and moral rights for the publications made accessible in the public portal are retained by the authors and/or other copyright owners and it is a condition of accessing publications that users recognise and abide by the legal requirements associated with these rights.

- Users may download and print one copy of any publication from the public portal for the purpose of private study or research.

- You may not further distribute the material or use it for any profit-making activity or commercial gain

- You may freely distribute the URL identifying the publication in the public portal 


\title{
Impacts of the invasive round goby (Neogobius melanostomus) on benthic invertebrate fauna: a case study from the Baltic Sea
}

\author{
Mikael van Deurs', Nicholas P. Moran ${ }^{1,2}$, Kristian Schreiber Plet-Hansen', \\ Grete E. Dinesen', Farivar Azour', Henrik Carl', Peter R. Møller ${ }^{3,4}$, Jane W. Behrens' \\ I Institute for Aquatic Resources (DTU Aqua), Technical University of Denmark, Kgs. Lyngby, Denmark \\ 2 Centre for Ocean Life - DTU Aqua, Technical University of Denmark, Kgs. Lyngby, Denmark 3 Natural \\ History Museum of Denmark, University of Copenhagen, Copenhagen, Denmark 4 Norwegian School of Fish- \\ eries, UiT Norwegian Arctic University, Tromsø, Norway
}

Corresponding author: Nicholas P. Moran (nicholaspatrickmoran@gmail.com)

Academic editor: Nicola Smith | Received 22 May 2021 | Accepted 28 July 2021 | Published 19 August 2021

Citation: van Deurs M, Moran NP, Plet-Hansen KS, Dinesen GE, Azour F, Carl H, Møller PR, Behrens JW (2021) Impacts of the invasive round goby (Neogobius melanostomus) on benthic invertebrate fauna: a case study from the Baltic Sea. NeoBiota 68: 19-30. https://doi.org/10.3897/neobiota.68.67340

\begin{abstract}
The round goby (Neogobius melanostomus) was first observed in the Baltic Sea in 1990 and has since displayed substantial secondary dispersal, establishing numerous dense populations where they may outcompete native fish and negatively impact prey species. There have been multiple round goby diet studies from both the Baltic Sea and the North American Great Lakes where they are similarly invasive. However, studies that quantify their effects on recipient ecosystems and, specifically, their impacts on the benthic invertebrate macrofauna are rare, particularly from European waters. In this study, we conducted the first before-after study of the potential effects of round goby on benthic invertebrate macrofauna taxa in marine-brackish habitats in Europe, focusing of two sites in the Western Baltic Sea, Denmark. Results were in line with those from the Great Lakes, indicating negative impacts on specific molluscan taxa (e.g. Cardiidae bivalves and Neritidae gastropods, which both showed a fall in detected densities of approximately $98 \%$ within the Guldborgsund Strait). In contrast, many other groups appeared to be largely unaffected or even show positive trends following invasion. Round goby gut content data were available at one of our study sites from the period immediately after the invasion. These data confirmed that round goby had in fact been preying on the subset of taxa displaying negative trends.
\end{abstract}

\section{Keywords}

Anthropogenic change, infauna, invasion impacts, invasive species, non-indigenous species, predation, predator-prey interactions

Copyright Mikael van Deurs et al. This is an open access article distributed under the terms of the Creative Commons Attribution License (CC BY 4.0), which permits unrestricted use, distribution, and reproduction in any medium, provided the original author and source are credited. 
The impacts of non-indigenous invasive animals can be closely related to their feeding behaviour, via increased predation pressure and resource competition for native species (Olenin et al. 2017). The round goby, Neogobius melanostomus (Pallas, 1814), is native to the Caspian, Black, Azov and Marmara Seas. From there, it was introduced to the Baltic Sea, most likely via ballast water, where it was first observed in the Gulf of Gdansk in 1990 (Kotta et al. 2015). At the same time, the species was also observed in the North American Great Lakes (Kornis et al. 2012). Today, three decades after these first observations, the species has displayed pronounced secondary dispersal in both regions and is now common throughout large parts of the Baltic Sea (Kotta et al. 2015; Puntila et al. 2018) and in three of the four Great Lakes (Corkum et al. 2004; Kornis et al. 2012). They are also found in numerous freshwater systems in Central and Western Europe (Kornis et al. 2012).

Round goby is a bottom-dwelling fish that occurs in a wide range of seabed habitats, from soft substrates (e.g. mud and sand, both with and without vegetation) to hard substrates (e.g. natural boulder reefs or man-made structures like harbour walls and jetties; Young et al. 2010; Kornis et al. 2012). Round gobies possess several invasive characteristics, such as high competitive ability for territory and prey, a broad diet, dispersal ability and broad temperature and salinity tolerances (Kornis et al. 2012; Azour et al. 2015; Behrens et al. 2017; Christensen et al. 2021; Ericsson et al. 2021). As such, the round goby is generally thought to have negative impacts on recipient ecosystems and indigenous taxa.

A handful of studies from freshwater systems in the Great Lakes Region have found evidence that round gobies outcompete indigenous fish species for space and food and may predate on both fish eggs and offspring (e.g. Chotkowski and Marsden 1999; Balshine et al. 2005). Competition with native fish has also been described in European waters (Karlson et al. 2007; Matern et al. 2021), although other studies have not detected effects on other fish species (e.g. Janáč et al. 2016; Piria et al. 2016). In relation to benthic invertebrate macrofauna, studies available from the freshwater Great Lakes system have investigated invertebrate abundances before and after invasion or compared tributaries with and without round goby populations (Lederer et al. 2008; Kipp and Ricciardi 2012; Barrett et al. 2017; Pennuto et al. 2018). These studies often find that round goby invasion has the capacity to alter species compositions and reduce the biomass of certain taxa, for example, in dreissenid bivalves (Lederer et al. 2008) and prosobranch gastropods (Barrett et al. 2017).

In European inlet waters and the marine and brackish habitats of the Baltic Sea, before-after studies of their impacts on the invertebrate macrofauna appear to be nonexistent. In contrast, studies of their diet are quite common (e.g. Polačik et al. 2009; Skabeikis and Lesutienè 2015; Nurkse et al. 2016; Piria et al. 2016; Oesterwind et al. 2017; Schwartzbach et al. 2020), along with a recent valuable experimental field study testing the effects of goby presence on native fauna using caged areas (i.e. goby presence vs. absence, Henseler et al. 2021). The rarity of before-after studies may be due to the difficulties and costs of obtaining site-specific abundance data of benthic fauna communities immediately prior to and after an invasion. This lack of studies is concerning as 
the limited knowledge of round gobies impacts on Baltic Sea ecosystems and communities has been identified as key a barrier to their management (Ojaveer and Kotta 2015). Therefore, the aim of this study was to test the hypothesis that round goby invasions in the Baltic Sea impact these recipient ecosystems by reducing the abundance of prey taxa.

We focused on two sites in south-eastern Denmark, Guldborgsund and Stege Bugt (see specific locations in Suppl. material 1: Figure S1). The first round goby observation along the main coastline of Denmark was made in Guldborgsund in 2009. By 2010, they were abundant throughout Guldborgsund and, by 2013, had reached an average density of 1.9 individuals per $\mathrm{m}^{2}$ (Azour et al. 2015). Round gobies were not observed at Stege Bugt until 2011 (Azour et al. 2015), which was likely colonised via secondary dispersal from Guldborgsund. Both are shallow brackish areas where local fishermen continue to catch large quantities of round goby as bycatch (Brauer et al. 2020).

Benthic invertebrate macrofauna data from fixed sampling stations in Guldborgsund and Stege Bugt, collected as part of the Danish national NOVANA marine monitoring programme database (Surface Water Database, ODA: https://odaforalle.au.dk) were mined. All fauna samples were collected in spring using a HAPS core sampler (seabed area: $0.0143 \mathrm{~m}^{2}$ ) and multiple samples were taken in each sampling-year (Table 1; Hansen et al. 2017; McLaverty et al. 2020). Species/taxa count data were extracted for the period 2006-2015 from these areas (i.e. ca. four years prior to and four years after invasion), including at least one sampling-year immediately prior to the first goby sighting and at least two sampling-years in a 2-5 year period following their first sighting. In Stege Bugt, invertebrate data were available in spring 2011 (also the year of the first round goby sighting), so for the purposes of this analysis, we considered data from spring 2011 to represent pre-impact abundances. NOVANA data are recorded to species, genus or occasionally higher taxonomic levels, therefore, for our analysis, we defined 20 broader taxonomic groups to aggregate the raw data to order and family levels where possible (see Suppl. material 1: Table S1 for full details of our taxonomic groupings). Species that were rarely detected in samples (in $<5 \%$ of cores) and could not be combined into order or family level groupings were excluded from analysis. All groupings were monophyletic, except Littorinimorpha, which we separated, based on morphological differences into two groups: larger periwinkle species (e.g. Littorina sp., as 'Littorinimorpha (large)') and several species of much smaller sea snails (e.g. Hydrobia sp. and Rissoa sp., as 'Littorinimorpha (small)', generally $<5 \mathrm{~mm}$ ), so that the responses of these morphologically-distinct groupings could be assessed separately.

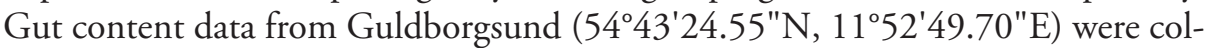
lected in autumn (November) 2010, in the year immediately following their first arrival in 2009 and immediately preceding the first post-impact sampling at the site. A total of 297 round gobies measuring $7.5-17 \mathrm{~cm}$ total length were collected with eel traps set overnight in shallow waters $(1-5 \mathrm{~m})$. Gobies were frozen $\left(-20^{\circ} \mathrm{C}\right)$ until processed. The presence/absence and count data for prey detected in gut samples were identified to species where possible. Given the few hours from capture until freezing, there is a risk that soft bodied and very small food items might have been underestimated. 
Count data per core sample (aggregated to our taxa groupings) were analysed using general linear mixed effect models for each site ('brms' package v. 2.14.4, Bürkner 2017; negative binomial distribution, log-link function with default non-informative priors, chains $=2$ chains, iterations $=6000$, warm-up $=2000$ ). A round goby beforeafter impact fixed effect ('BA') was included, with taxonomic groupings included as a random effect with random slopes (i.e. 'BA/TaxaGroup'). Taxa-specific BA slopes were extracted from posterior distributions with $95 \%$ credible intervals to infer positive and negative impacts of goby invasion on each taxon's abundance. Sampling year and core sample ID were also included as random effects to account for non-independence within samples and sampling seasons. Separate models were used for each site (for full model specifications, see Suppl. material 1: Table S2). Despite all sampling occurring in spring, samples were taken in March in 2015, while in previous years, sampling occurred in May, so a sensitivity analysis was conducted to ensure that this difference in timing did not influence our conclusions (see Suppl. material 1: Sensitivity Analyses).

Gut content data from Guldborgsund were summarised as the percentage of total gut samples $(\mathrm{n}=297)$ that each taxon group was detected within (i.e. \% occurrence). Further exploratory analysis was also conducted to measure whether a taxon's prevalence in gut contents influenced the BA effect. First, taxa were categorised as present or absent, based on their detection (or not) within gut samples. To test whether the BA effect was more negative in the taxa detected in gut samples than those not detected, we tested for an interaction between BA and taxa presence ('BA*Presence', Guldborgsund data only, using model specifications as above, also see Suppl. material 1: Table S2). To test if there was an overall positive or negative BA impact in each category of taxa, two separate models were used to estimate the BA effect for present and non-present subsets of taxa (Guldborgsund data only).

All credibility intervals below are $95 \%$ intervals. Statistically-significant effects are inferred from credibility intervals not overlapping zero. Model performance was assessed by checking diagnostic plots to ensure chains were well mixed and convergence was confirmed (Rhat $=1.00$, zero divergent transitions after warm-up). Conditional $R^{2}$ values (' $R_{\text {cond }}^{2}$ ) were estimated as a measure of the total amount of variance explained by each model (function 'r2_bayes', 'performance' package v. 0.7.0, Lüdecke et al. 2021). Additionally, sensitivity analyses were conducted to check whether our results were sensitive to zero-inflation (see Suppl. material 1: Sensitivity Analyses). All data, models and code are available at the Open Science Framework (https://doi. org/10.17605/OSF.IO/T5R4F)

Taxa-specific BA effects showed non-zero negative responses for Cardiidae bivalves and Neritidae gastropods at both sites, while Bryozoa was the only grouping with positive responses at both sites (Figure 1). Site specific changes at Guldborgsund were negative responses in Littorinimorpha (large) and Littorinimorpha (small) gastropods and positive responses in Capitellidae and Orbiniidae polychaetes (Figure 1a). Site specific changes at Stege Bugt were negative responses in Lymnaeidae gastropods and Chironomidae insects and positive responses in crustacean groups Isopoda and Amphipoda, as well as Spionidae polychaetes (Figure 1b). Overall BA effect estimates across all taxa 

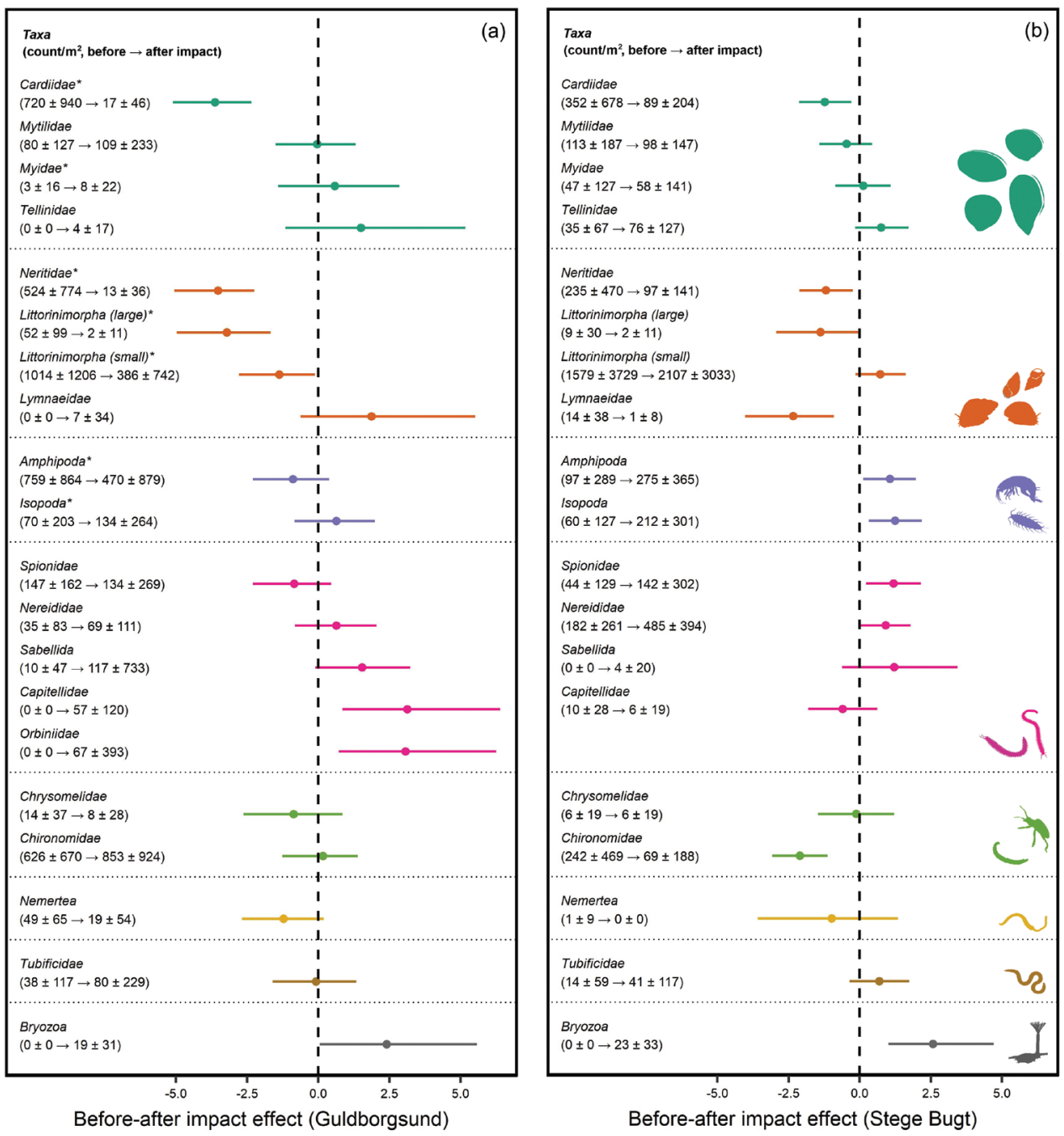

Figure I. Taxa-specific before-after (BA) effects for (a) Guldborgsund and (b) Stege Bugt (with 95\% credibility intervals). Positive or negative effects (on taxa counts per sample) that do not overlap zero are interpreted as showing a change in abundance following the arrival of round gobies. Mean densities per square meter $( \pm$ s.d.) in samples before and after invasion are also shown for each taxon group. Taxa groupings are arranged by class/phylum groupings by: (from top to bottom) class Bivalvia, class Gastropoda, class Malacostraca, class Polychaeta, class Insecta, phylum Nemertea, class Clitellata, class Bryozoa. Note: Orbiniidae were not detected at Stege Bugt, so were not included in analysis for that site.

were close to zero on both sites (Gulborgsund: BA: -0.04 [-4.09, 4.05], intercept = $-1.12[-4.78,2.31], \mathrm{R}^{2}$ cond $=0.51[0.46,0.56]$; Stege Bugt: BA: -0.07 [-3.58, 3.54], intercept $\left.=-1.12[-3.85,1.27], \mathrm{R}_{\text {cond }}^{2}=0.31[0.22,0.42]\right)$.

Of our twenty taxa groupings, seven were found in gut samples from Guldborgsund (Fig. 2a), of which Littorinimorpha (small) was the most common group de- 


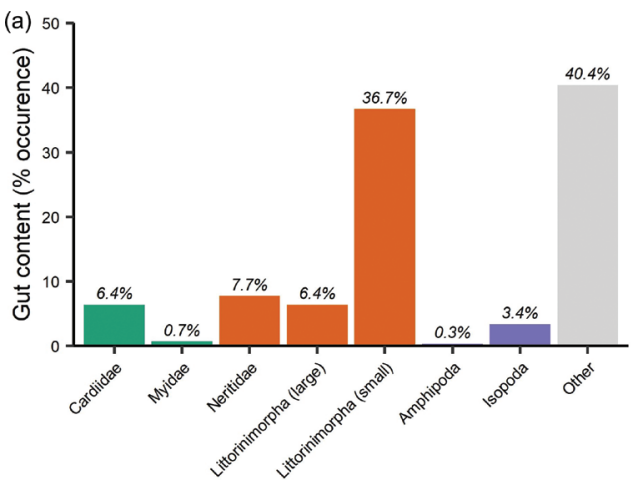

(b)

Figure 2. Gut content data for round gobies at Guldborgsund in 2011, including (a) the percentage occurrence of taxa groupings in gut content of $(\mathrm{n}=297 \mathrm{fish})$ and $(\mathbf{b})$ the overall BA effect estimates for Guldborgsund for all taxa (from the full site model), as well as present and absent subsets of taxa (with 95\% credibility intervals). 'Other' taxa found in gut contents were primarily mobile taxa that are poorly detected in HAPS core data (e.g. Palaemon adspersus, Palaemon elegans) and fish (Gasterosteus aculeatus, round goby scales).

tected. Several bentho-pelagic species (e.g. Palaemon spp., Gasterosteus aculeatus) were detected in the gut content, but were obviously not represented in core samples. The BA effect was influenced by an interaction with prey presence (BA*Presence: -2.66 $[-4.63,-0.91]$, intercept $\left.=-2.04[-5.85,1.31], \mathrm{R}_{\text {cond }}^{2}=0.52[0.46,0.56]\right)$, i.e. the $\mathrm{BA}$ effect was more negative for taxa found in gut samples than in taxa that were absent from gut samples. The overall BA effect estimate for taxa present in gut contents was negative, but overlapped zero (BA: $-1.91[-5.86,2.23]$, intercept $=0.43[-3.28,4.08]$, $\mathrm{R}_{\text {cond }}^{2}=0.50[0.39,0.58]$, Figure $2 \mathrm{~b}$ ), while the estimate for taxa absent from gut contents was slightly positive, but also overlapped zero (BA: 0.72 [-3.80, 4.87], intercept $=-1.95[-5.80,1.95], \mathrm{R}_{\text {cond }}^{2}=0.56[0.51,0.61]$, Figure $\left.2 \mathrm{~b}\right)$.

These results represent the first test for the effects of round goby invasion on benthic invertebrate macrofauna in marine/brackish environments. We found that a subset of largely molluscan taxa appear to be negatively impacted by goby invasions. For example, the strongest negative effect at Gulborgsund was in Cardiidae bivalves, where detected densities fell approximately 98\% after invasion, while in Stege Bugt, the density of Lymnaeidae gastropods fell approximately $94 \%$. This is generally consistent with the handful of studies available from the Great Lakes Region (i.e. freshwater environments). A study from the upper St. Lawrence River concluded that gastropod richness and median size declined as goby numbers increased, whereas dreissenid bivalves were unaffected and mainly avoided by the round goby (Kipp and Ricciardi 2012). In contrast, in Lake Michigan, dreissenids declined after the invasion of round goby, together with isopods, amphipods, trichopterans and gastropods (Lederer et al. 2008). The negative effect on dreissenids (which are also invasive species of Ponto-Caspian origin) was found to be caused by predation, whereas the effect on the rest of the benthic invertebrate community may have been indirect (i.e. loss of microhabitat and dreissenids pseudo-faeces) (Lederer et al. 2008). Notably, dreissenids do not occur in this area of 
Table I. Overview of NOVANA benthic fauna samples used in the present study.

\begin{tabular}{lcc}
\hline \multicolumn{1}{c}{ Sampling site (latitude/longitude) } & Pre-impact samples (n, year) & Post-impact samples (n, year) \\
\hline Guldborgsund $\left(54.70714^{\circ} \mathrm{N}, 11.86273^{\circ} \mathrm{E}\right)$ & $20(2007-$ May $)$ & 30 (2011-May); 42 (2013-May); 42 (2015-March) \\
Stege Bugt $\left(54.99996^{\circ} \mathrm{N}, 12.22708^{\circ} \mathrm{E}\right)$ & $20(2009-$ May): 42 (2011-May) & 42 (2013-May): 42 (2015-March) \\
\hline
\end{tabular}

the Baltic Sea, potentially due to salinity limitations (Werner et al. 2012), but round goby-dreissenid interactions may be more prevalent in lower salinity and freshwater areas of the Baltic catchment. Interestingly, some invertebrates, such as oligochaetes and chironomids, increased in numbers in an invaded bay in Lake Ontario as the gastropods disappeared (Barrett et al. 2017). Increases in abundance were also observed at our sites, particularly in some polychaete groups. This may suggest that the goby can have indirect positive effects on certain taxa: for example, by foraging selectively on certain groups, they may decrease the levels of resource competition for others.

The strong negative effect on gastropods (and to some extent bivalves) seems to be a recurring phenomenon in many of the Great Lakes studies (Kipp and Ricciardi 2012; Pennuto et al. 2018; Barrett et al. 2017). Similarly, previous gut content-based European studies and one field experiment support the notion that round goby show a preference for certain molluscs (e.g. Borza et al. 2009; Oesterwind et al. 2017; Henseler et al. 2021). The present study supports this and, especially for Neritidae and Cardiidae gastropods, strong negative effects were found that were clearly reflected in their observed densities before and after invasion. For example, the average observed density per square metre of both taxa fell by approximately $98 \%$ at Guldborgsund, with Stege Bugt showing similar, but more modest decreases of 59\% (Neritidae) and 75\% (Cardiidae). A strong negative impact on certain gastropods in these areas is a particular concern, as several studies from the Great Lakes Region have highlighted the risk of trophic cascades leading to increased algal biomass as gastropod grazing pressure is reduced (Kipp and Ricciardi 2012; Pennuto et al. 2018; Barrett et al. 2017), potentially signalling a risk of broader changes to ecosystem function and community structure in invaded areas.

As there was a lack of appropriate control sites (i.e. we could not identify a comparable non-impacted site with similar physical parameters, such as depth and salinity and with comparable macrofauna sampling intensity), we therefore lack the ability to directly infer causality between the goby invasion and observed changes. As such, observed trends (negative or positive) should be viewed cautiously. An additional shortcoming of the NOVANA data is the poor detection of mobile taxa, such as decapods (Palaemon spp.), which this and other studies in the Baltic have found to be a substantial component of round goby diets (Kornis et al. 2012). Single method monitoring programmes will tend to produce blind spots for certain taxa and limit our ability to measure impacts across the full community.

To mitigate the negative impacts of anthropogenic pressures on our aquatic environments, empirical data are required to plan and prioritise management efforts (Liu et al. 2008). In the Baltic Sea, there is a specific lack of knowledge on the impacts of non-indigenous species on native fauna (Ojaveer and Kotta 2015). Therefore, with 
this study, we hope to highlight the utility (and some limitations) of environmental monitoring data to assess the impacts of non-indigenous species. In this context, it is important to consider both positive and negative effects of non-indigenous species on ecosystems and our broad analysis approach across a wide range of taxa suggests that, while some groups appear to be severely impacted by this invasion, others may benefit from round goby presence. This also highlights the importance of reporting positive and negative findings (Fanelli 2012). In the anticipation that round goby will continue its secondary dispersal in the western Baltic Sea, we suggest that further multi-year regional monitoring programmes in advance of the invasion front would be valuable. Ideally, ecosystem monitoring would include appropriate control areas allowing before-after-control-impact analysis (as in Conner et al. 2016), which would allow us to better estimate and thus mitigate the impacts of the round goby invasion in northern European waters.

\section{Acknowledgements}

We acknowledge the Danish National Monitoring Program (NOVANA) for making data available and also Inge B. Enghoff, Kathe Jensen and Tom Schiøtte, Natural History Museum of Denmark are thanked for help with ID of food items. This project has received funding from the European Union's Horizon 2020 Research and Innovation Programme under the Marie Sklodowska-Curie grant agreement No 836937 (NPM) and the Danish Environmental Protection Agency (JWB, MvD, GED, KSP-H). The Centre for Ocean Life is a VKR centre of excellence supported by the Villum Foundation. The Centre for Ocean Life is a VKR centre of excellence supported by the Villum Foundation. Fisherman Benni Christensen is thanked for catching round gobies in Guldborgsund for the stomach content study.

\section{References}

Azour F, van Deurs M, Behrens J, Carl H, Hüssy K, Greisen K, Ebert R, Møller PR (2015) Invasion rate and population characteristics of the round goby Neogobius melanostomus: effects of density and invasion history. Aquatic Biology 24: 41-52. https://doi.org/10.3354/ab00634

Balshine S, Verma A, Chant V, Theysmeyer T (2005) Competitive interactions between round gobies and logperch. Journal of Great Lakes Research 31(1): 68-77. https://doi. org/10.1016/S0380-1330(05)70238-0

Barrett KB, Haynes JM, Warton DI (2017) Thirty years of change in a benthic macroinvertebrate community of southwestern Lake Ontario after invasion by four Ponto-Caspian species. Freshwater Science 36: 90-102. https://doi.org/10.1086/689576

Behrens JW, van Deurs M, Christensen EAF (2017) Evaluating dispersal potential of an invasive fish by the use of aerobic scope and osmoregulation capacity. PLoS ONE 12(4): e0176038. https://doi.org/10.1371/journal.pone.0176038 
Borza P, Erős T, Oertel N (2009) Food resource partitioning between two invasive gobiid species (Pisces, Gobiidae) in the littoral zone of the River Danube, Hungary. International Review of Hydrobiology 94(5): 609-621. https://doi.org/10.1002/iroh.200911134

Brauer M, Behrens JW, Christoffersen M, Hyldig G, Jacobsen C, Björnsdottir KH, van Deurs M (2020) Seasonal patterns in round goby (Neogobius melanostromus) catch rates, catch composition, and dietary quality. Fisheries Research 222: e105412. https://doi.org/10.1016/j. fishres.2019.105412

Bürkner PC (2017) brms: An R package for Bayesian multilevel models using Stan. Journal of Statistical Software 80: 1-28. https://doi.org/10.18637/jss.v080.i01

Conner MM, Saunders WC, Bouwes N, Jordan C (2016) Evaluating impacts using a BACI design, ratios, and a Bayesian approach with a focus on restoration. Environmental Monitoring and Assessment 188(555): 1-14. https://doi.org/10.1007/s10661-016-5526-6

Corkum LD, Sapota MR, Skora KE (2004) The round goby, Neogobius melanostomus, a fish invader on both sides of the Atlantic Ocean. Biological Invasions 6(2): 173-181. https:// doi.org/10.1023/B:BINV.0000022136.43502.db

Chotkowski MA, Marsden JE (1999) Round goby and mottled sculpin predation on lake trout eggs and fry: field predictions from laboratory experiments. Journal of Great Lakes Research 25(1): 26-35. https://doi.org/10.1016/S0380-1330(99)70714-8

Christensen EA, Norin T, Tabak I, van Deurs M, Behrens JW (2021) Effects of temperature on physiological performance and behavioral thermoregulation in an invasive fish, the round goby. Journal of Experimental Biology 224(1): jeb237669. https://doi.org/10.1242/jeb.237669

Ericsson P, Persson A, Behrens JW, Brodin T, Hirsch PE, Sundelin A, van Deurs M, von Friesen LW, Nilsson PA (2021) Personality-dependent inter-and intraspecific foraging competition in the invasive round goby, Neogobius melanostomus. Journal of Fish Biology 98(5): 1234-1241. https://doi.org/10.1111/jfb.14652

Fanelli D (2012) Negative results are disappearing from most disciplines and countries. Scientometrics 90(3): 891-904. https://doi.org/10.1007/s11192-011-0494-7

Hansen JLS, Carausu MC, Deding J (2017) M19 Blødbundsfauna. Datateknisk anvisning for marin blødbundsfauna (DM05 version 2): 1-21. https://docplayer.dk/54953436-Titeldatateknisk-anvisning-for-marin-bloedbundsfauna.html

Henseler C, Oesterwind D, Kotterba P, Nordström MC, Snickars M, Törnroos A, Bonsdorff E (2021) Impact of round goby on native invertebrate communities-An experimental field study. Journal of Experimental Marine Biology and Ecology 541: e151571. https://doi. org/10.1016/j.jembe.2021.151571

Janáč M, Valová Z, Roche K, Jurajda P (2016) No effect of round goby Neogobius melanostomus colonisation on young-of-the-year fish density or microhabitat use. Biological Invasions 18(8): 2333-2347. https://doi.org/10.1007/s10530-016-1165-7

Karlson AML, Almqvist G, Skora KE, Appelberg M (2007) Indications of competition between non-indigenous round goby and native flounder in the Baltic Sea. ICES Journal of Marine Science 64: 479-486. https://doi.org/10.1093/icesjms/fsl049

Kipp RM, Ricciardi A (2012) Impacts of the Eurasian Round Goby (Neogobius melanostomus) on benthic communities in the upper St. Lawrence River. Canadian Journal of Fisheries and Aquatic Sciences 69: 469-486. https://doi.org/10.1139/f2011-139 
Kornis MS, Mercado-Silva N, Van der Zanden MJ (2012) Twenty years of invasion: a review of round goby (Neogobius melanostomus) biology, spread and ecological implications. Journal of Fish Biology 80(2): 235-285. https://doi.org/10.1111/j.1095-8649.2011.03157.x

Kotta J, Nurkse K, Puntila R, Ojaveer H (2015). Shipping and natural environmental conditions define the distribution of the invasive non-indigenous round goby Neogobius melanostomus in a regional sea. Estuarine, Coastal and Shelf Science 169: 15-24. https://doi. org/10.1016/j.ecss.2015.11.029

Lederer A, Janssen J, Reed T, Wolf A (2008) Impacts of the introduced Round Goby (Apollonia melanostoma) on dreissenids (Dreissena polymorpha and Dreissena bugensis) and on macroinvertebrate community between 2003 and 2006 in the littoral zone of Green Bay, Lake Michigan. Journal of Great Lakes Research 34: 690-697. https://doi.org/10.1016/ S0380-1330(08)71611-3

Lehtiniemi M, Bonsdorff E, Funk S, Herlevi H, Huwer B, Jaspers C, Kotta J, Kotterba P, Lesutiene J, Margonski P, Mattern S (2017) Report assessing the effects of key NIS on ecosystem functioning. https://doi.org/10.3289/BIO-C3_D2.3

Liu Y, Gupta H, Springer E, Wagener T (2008) Linking science with environmental decision making: Experiences from an integrated modelling approach to supporting sustainable water resources management. Environmental Modelling \& Software 23(7): 846-858. https:// doi.org/10.1016/j.envsoft.2007.10.007

Lüdecke D, Ben-Shachar MS, Patil I, Waggoner P, Makowski D (2021) Assessment, Testing and Comparison of Statistical Models Using R. PsyArXiv (pre-print). https://psyarxiv.com/vtq8f/

Matern S, Herrmann J-P, Temming A (2021) Differences in diet compositions and feeding strategies of invasive round goby Neogobius melanostomus and native black goby Gobius niger in the Western Baltic Sea. Aquatic Invasions 16(2): 314-328. https://doi.org/10.3391/ ai.2021.16.2.07

McLaverty C, Eigaard OR, Dinesen GE, Gislason H, Kokkalis A, Erichsen AC, Petersen JK (2020) High-resolution fisheries data reveal effects of bivalve dredging on benthic communities in stressed coastal systems. Marine Ecology Progress Series 642: 21-38. https:// doi.org/10.3354/meps13330

Nurkse K, Kotta J, Orav-Kotta H, Ojaveer H (2016) A successful non-native predator, round goby, in the Baltic Sea: generalist feeding strategy, diverse diet and high prey consumption. Hydrobiologia 777(1): 271-281. https://doi.org/10.1007/s10750-016-2795-6

Oesterwind D, Bock C, Förster A, Gabel M, Henseler C, Kotterba P, Menge M, Myts D, Winkler HM (2017) Predator and prey: the role of the round goby Neogobius melanostomus in the western Baltic. Marine Biology Research 13(2): 188-197. https://doi.org/10.1080/17 451000.2016.1241412

Olenin S, Gollasch S, Lehtiniemi M, Sapota M, Zaiko A (2017) Biological invasions. In: Snoeijs-Leijonmalm P, Schubert H, Radziejewska T (Eds) Biological oceanography of the Baltic Sea. Springer Science \& Business Media, Berlin, 193-232. https://doi.org/10.1007/97894-007-0668-2_5

Ojaveer H, Kotta J (2015) Ecosystem impacts of the widespread non-indigenous species in the Baltic Sea: literature survey evidences major limitations in knowledge. Hydrobiologia 750(1): 171-185. https://doi.org/10.1007/s10750-014-2080-5 
Pennuto CM, Cudney KA, Janik CE (2018) Fish invasion alters ecosystem function in a small heterotrophic stream. Biological Invasions 20: 1033-1047. https://doi.org/10.1007/ s10530-017-1609-8

Polačik M, Janáč M, Jurajda P, Adámek Z, Ondračková M, Trichkova T, Vassilev MI (2009) Invasive gobies in the Danube: invasion success facilitated by availability and selection of superior food resources. Ecology of Freshwater Fish 18(4): 640-649. https://doi. org/10.1111/j.1600-0633.2009.00383.x

Piria M, Jakšić G, Jakovlić I, Treer T (2016) Dietary habits of invasive Ponto-Caspian gobies in the Croatian part of the Danube River basin and their potential impact on benthic fish communities. Science of the Total Environment 540: 386-395. https://doi.org/10.1016/j. scitotenv.2015.05.125

Puntila R, Strake S, Florin AB, Naddafi R, Lehtiniemi M, Behrens JW, Kotta J, Oesterwind D, Putnis I, Smolinski S, Wozniczka A, Ojaveer H, Lozys L, Uspenskiy A, Yurtseva A (2018) Abundance and distribution of Round goby (Neogobius melanostomus). HELCOM Baltic Sea Environment Fact Sheets. https://helcom.fi/wp-content/uploads/2020/06/BSEFSAbundance-and-distribution-of-round-goby.pdf

Sapota MR (2004) The round goby (Neogobius melanostomus) in the Gulf of Gdánsk - a species introduction into the Baltic Sea. Hydrobiologia 514: 219-224. https://doi.org/10.1023/ B:hydr.0000018221.28439.ae

Skabeikis A, Lesutienė J (2015) Feeding activity and diet composition of round goby (Neogobius melanostomus, Pallas 1814) in the coastal waters of SE Baltic Sea. Oceanological and Hydrobiological Studies 44(4): 508-519. https://doi.org/10.1515/ohs-2015-0048

Skora K, Rzeznik J (2011) Observations on Diet Composition of Neogobius melanostomus Pallas 1811 (Gobiidae, Pisces) in the Gulf of Gdansk (Baltic Sea). Journal of Great Lakes Research 27(3): 290-299. https://doi.org/10.1016/S0380-1330(01)70644-2

Schwartzbach A, Behrens JW, Svendsen JC, Nielsen P, van Deurs M (2020) Size-dependent predation of round goby Neogobius melanostomus on blue mussels Mytilus edulis. Fisheries Management and Ecology 27: 215-218. https://doi.org/10.1111/fme.12400

Werner M, Michalek M, Strake S (2012) Abundance and distribution of the Zebra mussel (Dreissena polymorpha). HELCOM Baltic Sea Environment Fact Sheets. https://helcom.fi/wpcontent/uploads/2020/06/BSEFS-Abundance-and-distribution-of-the-Zebra-mussel.pdf

Young JA, Marentette JR, Gross C, McDonald JI, Verma A, Marsh-Rollo SE, Macdonald PD, Earn DJ, Balshine S (2010) Demography and substrate affinity of the round goby (Neogobius melanostomus) in Hamilton Harbour. Journal of Great Lakes Research 36(1): 115-122. https://doi.org/10.1016/j.jglr.2009.11.001 


\section{Supplementary material I}

S1. Sampling Areas (Figure S1); S2. Taxonomic Groupings (Table S1); S3. Model Specifications (Table S2); S4. Sensitivity Analyses (Table S3, Figure S2)

Authors: Mikael van Deurs, Nicholas P. Moran, Kristian Schreiber Plet-Hansen, Grete E. Dinesen, Farivar Azour, Henrik Carl, Peter R. Møller, Jane W. Behrens

Data type: document

Explanation note: Map of study locations; Table of taxonomic groupings for analysis; Model specifications for analysis; and, Sensitivity analysis.

Copyright notice: This dataset is made available under the Open Database License (http://opendatacommons.org/licenses/odbl/1.0/). The Open Database License $(\mathrm{ODbL})$ is a license agreement intended to allow users to freely share, modify, and use this Dataset while maintaining this same freedom for others, provided that the original source and author(s) are credited.

Link: https://doi.org/10.3897/neobiota.68.67340.suppl1 